\title{
Qualitative methods for engaging students in performance measurement
}

\begin{tabular}{|r|l|}
\hline Journal: & Information and Learning Science \\
\hline Manuscript ID & ILS-09-2017-0093 \\
\hline Manuscript Type: & Article \\
\hline Keywords: & $\begin{array}{l}\text { qualitative methods, academic libraries, focus groups, User Experience, } \\
\text { ethnography, student engagement }\end{array}$ \\
\hline \multicolumn{3}{|c}{} \\
\\
\hline
\end{tabular}




\section{Qualitative methods for engaging students in performance measurement}

\section{Background and introduction}

This article will look at how libraries can engage with students in their performance measurement activities. In the modern 'student focused' university setting, quality assurance and continual service improvement have become increasingly important in the delivery of academic library services. Working in partnership with their students, academic libraries can enable meaningful engagement, through qualitative methods which allow individual students to contribute to service development. Student engagement within universities is not a new phenomenon, but clarity as to what makes a strong student partnership has become more and more important as students and their institutions seek to define what sort of "collaborations" they are involved in together (Streeting and Wise, 2009). Working together on 'quality' is one such area and this manifests itself in libraries through engagement in performance measurement. The 2011 white paper "Higher Education: Students at the Heart of the System" set out a clear strategy for making the higher education system in the UK more accountable to students and to put them into a stronger position to influence the sector (Department for Business, Innovation, and Skills, 2011), and more recently this has been further validated through the 2016 white paper "Success as a Knowledge Economy: Teaching Excellence, Social Mobility and Student Choice" which stresses the importance of quality in higher education and student involvement in defining and shaping this (Department for Business, Innovation, and Skills, 2016).

\section{Method}

Through a review of relevant UK and US literature sources, discussion around the emergent themes and some case study examples, this paper will illustrate how effective student engagement through qualitative methods can contribute to the quality assurance, performance measurement and ultimate service improvement of academic libraries. A wide range of literature has been consulted including papers from both library and information science and educational studies disciplines. Much of the discussion from the literature is triangulated through referenced examples of student engagement in academic libraries and these are used throughout the paper. Many of the student engagement examples used are around the development of academic library space and a significant case study is used in order to illustrate some of the qualitative methods under discussion.

\section{$\underline{\text { Objectives }}$}


The main aim of the paper is to present, in a cohesive manner, a variety of qualitative methods used to engage students in order to measure performance in academic libraries. Where theory is discussed, real life examples are used to link this to practice and specific objectives of the paper include: establishing 'partnership' at the heart of student engagement and in doing so providing a framework for discussing particular student engagement practices; breaking down different approaches to student engagement in academic libraries and using 'space planning' as a real-life activity in which students are often engaged; discussing the application of specific qualitative methods of academic library student engagement including focus groups, reflective activities, and the ethnographic and anthropological techniques afforded from a User Experience methodology.

\section{Performance measurement in academic libraries}

In discussing the theme of assessing the value and impact of academic library services it is necessary to review the literature available about quality and performance measurement in libraries.

"Performance measurement is central to library management, since without a firm grasp on what is actually being achieved it is impossible to move forward to improved service, or even to maintain the status quo" (Brophy, 2006, p.1)

Academic librarians have measured the quality, performance and the impact of their services for a long time in order to inform how they operate in the present and how they might operate in the future. That is to say the present measure of performance, and the judgement made on how well the library is performing provides the benchmark as to how the library should be performing in the future. Essentially, performance measurement and evaluation is used in order to make comparative assessments against standards and targets

With this in mind, academic libraries have always attempted to measure their performance in order to justify themselves through demonstrating value and impact, and to make business cases for resources and developments. Such measurements previously focused on usage of libraries and resources and metrics around quantities (e.g. number of visits, number of loans, number of downloads). Being able to generate quantitative data about library usage provides evidence as to how libraries are being used, how busy they are and how usage compares over time. In addition there are examples of many academic libraries use metrics and learner analytics to demonstrate impact on outcomes such as retention and achievement by students in their respective institutions. The JISC Library Impact Data Project is such an example, in that it demonstrates a quantitative method of assessing library impact which goes beyond standard usage metrics and attempts to demonstrate a causal 
relationship between library use and academic achievement (Stone, Patten and Ramsden, 2012)

However, alongside the use of quantitative methods, library managers are increasingly turning to qualitative methods in order to further enhance and strengthen their performance measurement activities. Qualitative and quantitative research methods are often dealt with separately and along with this division there is, according to Berg (2009, p.2) an unwritten hierarchy in research circles that quantitative research is considered to be more rigorous, more reliable and more precise. Traditionally, librarians, wishing to demonstrate rigour in their measures tended to favour the quantitative approaches as favoured by other social scientists. However with emergence of the importance of the 'library user' methods needed to be deployed which "attempt to understand behaviour and institutions by getting to know the persons involved and their values, rituals, symbols, beliefs, and emotions" (Nachmias and Worth-Nachmias, 2008, p.257). In other words the measures that today's academic librarian requires need to be meaningful and need to be able to describe the value and the impact that the library has on individual students.

"Quantitative methodology assumes the objective reality of social facts, where qualitative assumes social constructions of reality" (Gorman and Clayton, 2005 ; 24) This suggests that where quantitative data obtained through survey questions and statistical returns presents us with definitive factual information (i.e. $x$ number of book issues, $x \%$ of satisfied users, etc.), qualitative methods will help to validate those facts through 'real life' examples. Qualitative methods for performance measurement in library and information services are often more revealing when they are based on direct contact with library users. Indeed, such direct contact can help to validate quantitative findings. Qualitative methods encourage observation, discussion and reflection and can help librarians to identify issues and problems and get to the details of such situations, or conversely can help to demonstrate the impact and value that a library service has on its users.

\section{Partnership and student engagement in Higher Education}

Historically, student engagement has been around for some time and in recent years has become a catch all term for involving students in collective problem solving in higher education institutions (Owen, 2013). In most higher education institutions student engagement is used effectively as a tool to enhance learning and teaching (Trowler, 2010), and indeed, until recently, student representation and student feedback into teaching and learning activities was the accepted means of achieving such engagement (Little et al. 2009). Engagement occurs when there is a strong partnership between the student and the area of the university in which they are working or dealing with. An effective partnership, in a 
university setting requires a relationship with the students which enables dialogues or activities which are mutually beneficial. The whole concept of a partnership is that there are multiple "partners" involved (e.g. academics, libraries, service departments, students, etc.), all of whom need to be proactive in the relationship.

A piece of research by Carey (2013a) into student participation and engagement in their curriculum development demonstrated that partnership is not a one off exchange but should be an ongoing process that should characterise the whole student experience. The case study actively engages students at all stages of the curriculum development cycle and the subsequent research provides an opportunity to explore engagement procedures that extend beyond the reliance on performance and evaluation data (e.g. from post module surveys, etc.) which are often a proxy for an authentic student voice (Coates, 2005)

At this point it is worthwhile looking at the concept of "students as customers" or the 'consumer model' of higher education in the UK. This notion brings with it much discussion with many commentators suggesting that a consumer culture within higher education in the $\mathrm{UK}$ is detrimental to the pedagogical aspects of the university experience in that the educational experience becomes viewed as a commodity and the actual value of that experience is lost (Molesworth et al. 2009). However, it can also be argued that the concept of 'the student voice' has come directly from this consumerist model. Subsequently, higher education has sought many ways in which to engage the student as 'customers' and the notion of the student as such has been widely embraced by universities (Little et al. 2009). The "consumer" model has also brought with it many positive "student engagement" and "student experience" initiatives and universities are now increasingly concerned about meeting students' needs and demands and ensuring that students have a "voice" where decisions about the student experience are made (Maringe, 2010). It is important to note, that whilst some scholars accept that a 'consumer model' of higher education exists and might be the cause of an increase in student engagement activity, there is an equal amount of research which questions the notion of this model entirely and concludes that students themselves do not see themselves as customers or consumers of higher education and don't display consumerist behaviours in their engagement with their studies (Saunders, 2015; Tomlinson, 2017)

Regardless of its origins, student engagement is now seen as a means by which universities can get to understand and enhance the student experience and this is often now achieved by having student representation on decision making bodies (Trowler, 2010). Carey (2013b) suggests that student engagement has become increasingly part of higher education rhetoric 
and is seen as a means for universities to understand and enhance the student experience.

This has resulted from a growing consumerism in higher education and a drive for universities to form partnerships with students.

\section{Student engagement in libraries}

This drive to provide excellent student experiences have had a profound effect on how academic libraries engage with users, in order to seek feedback, work in partnership and to continually improve and develop services in a responsive manner. There are many example of progressive and proactive student engagement methods in academic libraries in general over recent years.

Everitt (2015) talks about how at the School of Oriental and African Studies (SOAS) library, a range of tools are used to engage students in order to understand their needs and requirements. This includes techniques such as process mapping, web surveys, exit surveys and observational techniques, as well as suggestion and course feedback forms.

As well as developing library services, student engagement can also assist in performance measurement and provides key evidence to the impact and value that the modern academic library needs to continually demonstrate. Tilley (2013) suggests that being able to personalise library services, through a range of engagement activities, allows her to demonstrate the impact that her [personalised] library services have on her students. Another example of engagement demonstrating impact can be found in 'Customer Value Discovery' approach deployed at Nottingham Trent University, which asks the basic and fundamental question: what was it about the library service that helped you [the student], achieve success (McKnight and Berrington, 2008). In both these examples having a clear customer focus and an embedded approach to service evaluation is important in developing and demonstrating 'valued' academic library services.

As well as 'capturing the student voice' through methods such as those illustrated above, student engagement lends itself to more discursive techniques, which would fall naturally into the 'qualitative' side of research methods. Whether intentionally operating within a consumerist model, or driven by external kite-marks such as Customer Service Excellence, more and more academic libraries are engaging their students in dialogue in order to affirm their partnerships, measure their performance and ultimately improve services. What is interesting about this is the willingness of most, if not all, academic libraries (certainly in the UK) to adapt to this 'new managerialsm' has led to lots of creativity and innovation when it comes to qualitative methods of engaging with students. A selection of such examples 
include: the 'Are students at the heart of our processes' initiative at the University of Leicester library, in which students and library staff work in partnership reflecting on library processes (Aitkens et al, 2015); library critical friends and focussed discussion forums at Liverpool John Moores University (Appleton and Abernethy, 2013); and customer journey mapping in order to see how students interact with services and facilities at Birmingham City University (Andrews and Eade, 2013)

\section{Student engagement in library space planning}

Students can be engaged in all kinds of planning for academic library services an some of the above examples feature engagement initiatives in which students are consulted about the resources and facilities available to them in their libraries, as well service models and staff support activity. Qualitative methods can be applied in all of these areas, but one of the main areas of provision in which qualitative methods can be used to best effect is in the planning and design of library space. Students have opinions and thoughts about all aspects of library provision. With regard to the selection and availability of learning resources for examples (e.g.: texts, monographs, journal, e-journals, etc.) librarians will often to react to comments such as 'I can never find the books I need', 'there aren't enough psychology books' or 'not enough copies of reading list items' when they appear in surveys. Such reactive behaviour is almost expected within quality assurance and performance measurement frameworks in academic libraries, in that the library needs to be responsive and being able to acquire additional titles or copies of books is regarded as positive and responsive action. However, it is the area of library design and space planning, where students can truly have a 'voice' and effect decision making and continuous improvement, especially where qualitative techniques have been used in a proactive manner. There are some excellent examples in existence of this in academic libraries. It is also not a new concept as there is evidence of engaging students and users in academic library space design spanning the last twenty years. For example, in 2006, Bennett discusses the notion of asking key questions and setting objectives when designing higher education learning spaces and identifies student engagement through questioning them about their learning needs and behaviours as being a fundamental part of this (Bennett, 2006). Andrews, Wright and Raskin (2015) examine the various qualitative student engagement they have deployed at Cornell University over a period of eight years $(2007$ - 2015). Their longitudinal reflection includes techniques such as interviews, usability testing and anticipatory design exercises, all have which have helped to redesign the collaborative study spaces at their university library. A similar study from Victoria University of Wellington discusses different qualitative customer engagement techniques and illustrates this with some interesting case studies around how users were engaged in library space planning across a number of different 
initiatives. This included interactive feedback boards for a new build project and focus groups aimed at specifically engaging Maori students in planning the spaces in which to house library material with significant Maori content (Esson et al., 2012)

\section{Engagement through focus groups}

"Focus group interviews typically have five characteristics or features: (1) people, who (2) possess certain characteristics, (3) provide qualitative data (4) in a focused discussion (5) to help understand the topic of interest." (Krueger \& Casey, 2009) Focus groups had originally been popular in the commercial world amongst market researchers, but have since become an acceptable method for academic research. Once this was the case, the focus became less about consumer products and more about issues such as community, education, social issues and public policy (Morgan, 1997). Focus groups encourage discussion and reflection and well-constructed questioning can reveal deep and focused data, which is why this has become a standard method for data capture in social science research (Bloor et al., 2002)

The focus group is now a well-established qualitative method used in the social sciences and is used to generate broad discussion amongst participants which then narrows down to focus on particular key issues. The role of the facilitator in these situations is very important in encouraging positive discussion without actually directing or controlling the flow of the discussion.

Where this lends itself to academic libraries as a performance measurement method is in the discussion and reflection that it affords amongst student users. Students can often go into far more detail of a current issue or situation based on their own observations and experiences and their focused discussions can help to validate or triangulate data obtained through other quantitative methods such as surveys or observations.

Used in isolation and without any objectives, focus groups can sometimes become 'moaning sessions' for those participating. For this reason, it is important that the facilitator is skilled and focused and is able to lead the discussion effectively. Focus groups are one of the more common qualitative methods used by academic libraries and there is no shortage of examples of their effective use. Conrad and Alvarez 
(2016) provide a very informative discussion of why academic libraries should use focus groups and concentrate specifically on using focus groups to discuss library Web interfaces and platforms with students. In their discussions they suggest that focus groups can be an effective starting point, and whilst often don't lead to any immediate significant service improvements they do in fact provide lots of relevant data for larger decisions and often validate findings and data from elsewhere (i.e. library surveys)

Similarly, current examples of where focus groups have been used effectively in library space planning and design include an initiative at Newcastle University where a deliberate and systematic approach to student engagement was used to inform the refurbishment of two floors of the main university library. As part of a mixed method approach students were employed to take part in a number of engagement initiatives including observations and conducting exit polls as a well as conducting focus groups (Oddy, 2015). This is quite typical of academic libraries, in that those that are able to engage students, make use of focus groups as part of a wider mixed method. Often multiple sources of data are useful for triangulating and validating findings. Another useful example of this is the piece of work conducted at Liverpool John Moores University in which focus groups were used to initially surface student thoughts and feedback on their library and learning spaces, before being invited to complete reflective diaries in order to explore more deeply what students felt and thought about the spaces in which they learnt (Appleton, 2014)

\section{Engagement through reflective activities}

Reflective logs and diaries are also useful for confirming and validating data retrieved from other methods. That is they can provide anecdotal evidence of the findings of surveys or usage statistics, or further discussion to add to the findings of a focus group. As both a research method and a performance measure reflective diaries and logs come in for quite a lot of criticism. Slater (1990) regards them as recorded self-observations and as such suggests that they are too subjective to be effective as performance measurement. However, in her book "Research methods in information" Pickard suggest that they are unfortunately, largely overlooked and argues that they can be of use by offering insight into the behaviour, feelings and thoughts of those taking part (Pickard, 2006, p. 211). 
The above example from Liverpool John Moores University illustrates how reflective logs can be used alongside other methods such as focus groups and after first using reflective logs for engaging students in library space planning a further initiative was carried out where students were invited to the focus was on accessibility of electronic library services. Sykes (2015) discusses how the method has been effective, but its limits can be improved upon through some minor revisions (e.g. timing of reflective logs, encouraging students to discuss 'feelings', etc.) and there are plans to continue using reflective logs to engage students in future space planning and design projects.

A similar technique has been very successfully deployed in the library at Edge Hill University, who adopted a student diary mapping approach having discovered the success of the ERIAL ${ }^{1}$ project and the Library Study ${ }^{2}$ at Fresno State University (Delcore et al., 2009). Students were asked to complete real time diaries in which they recorded all their activities related to learning, including thoughts, feelings and barriers. The diaries included illustrative maps and photographs and students were then asked to reflect, through discussion with library staff, on their diary findings. The method has allowed for a unique insight into how library spaces are used by students and this will help to inform continual service improvements (Ramsden \& Carey, 2014)

\section{Engagement through User Experience (UX)}

The above mentioned focus group and reflective methods have become increasingly popular performance measurement methods utilised in academic libraries. This leads neatly into the final qualitative area that this paper will discuss, as both aforementioned methods fall under the User Experience umbrella. UX has become very popular as a qualitative research method in academic libraries over recent years. Priestner and Borg (2016) suggest that this is a response to the fact that the traditional quantitative metrics and measures used by academic libraries (e.g. statistics on footfall, holdings, loans, renewals, database use, downloads, views, social media followers, etc.) don't reveal anything about the success or quality of the interaction experienced by the library user and ultimately the value or impact that this has on the user, and that increasingly this is what academic libraries are asked to evidence. They suggest that the focus in UK higher education on 'student experience' has led library managers to look at how and why library users use libraries in the way that they 
do (as opposed to the ways in which librarians think that they use them) in order to better understand what users want from libraries. (Priestner \& Borg, 2016)

UX for libraries involves a suite of techniques based around first understanding and then improving the experience that users have when using libraries. One of the fundamental principles of UX is that it uses ethnographic methods to achieve this. Ethnography is "a way of studying cultures through observation, participation and other qualitative techniques with a view to better understanding the subject's point of view an experience of the world". (Priestner, 2015). Until recently UX was largely applied by libraries to the design and usability of websites and systems interfaces, but academic libraries have now shown willingness to interpret UX in a broader approach and now increasingly use ethnographic methods when exploring the UX experience in the design of their physical spaces (Bryant, Matthews \& Walton, 2009). The notion of 'design' is a key one within UX. The delivery of high quality, high performing library services is the aim of every library manager and effective services need to be 'designed'. Schmidt (2010) suggests librarians are quite often unknowingly involved in design, in as much as every operational management decision (e.g. about loan periods, where to house a collection, how to create access to a collection, introducing new services, etc.) are all decisions about the design of the library service. What UX does is ensure that the users' behaviours, use and expectation of the library service are behind any such decisions.

\section{Ethnography and anthropology}

UX in academic libraries makes use of a suite of techniques based around first understanding and then improving the experience that students have when using libraries. One of the fundamental principles of UX is that it uses ethnographic methods to achieve this. Ethnography in libraries has been around for some time and there exists a wealth of excellent and interesting case studies of successful ethnographic and anthropological library studies (Foster and Gibbons, 2007; Suarez, 2007; Delcore et al., 2009; White, 2009; Duke \& Asher, 2012). Similarly, there are well documented examples of library user engagement and involvement in academic library service deign (Trischler \& Kelly, 2016). In all these examples ethnographic techniques are used to observe and then further inform developments in many different aspects of library and information services and activity (e.g. collection management, resource discovery, information seeking behaviour, library instruction, space planning, etc.) 
In a similar way to the qualitative methods which have already been discussed, UX is particularly useful for engaging students in library space planning and design. UX effectively makes use of ethnographic approaches in order to see how library users actually use the resources, services and spaces provided by the library, which in turn can contribute to service improvement and development.

\section{$\underline{\text { UX methods }}$}

Examples of UX methods include: observation of user movement in the library (to see where users naturally physically travel to within their library spaces as opposed to where the librarians think they travel to); observation of activity within given spaces (to see how users naturally behave in demarked spaces and environments); walking though library spaces with users to observe and discuss how they use the library; focused discussion with library users about what works for them and what doesn't; diaries and reflective exercises about users' experience of the library; observation of alternative library spaces; directed storytelling; unstructured interviews; photo studies; cognitive mapping, etc.

By engaging students using one or more of these methods, library managers are able to generate significant quantities of data which then needs to be analysed. Ramsden (2016) discusses how data from UX projects needs to be effectively collected and analysed, and that there needs to be a coding process and a critical standpoint needs to be assumed.

\section{$\underline{\text { UAL UX case study }}$}

A good example of the use of UX as a means to engage students in the planning and design of library spaces is that of the University of the Arts London (UAL) (Appleton et al., 2016). During 2015, the university announced several estates and new build projects, all of which had huge implications for the university's Library Services. Being involved in new build projects allowed Library Services the opportunity to consider how best to engage and consult students in the development of their physical library spaces. In seeking a method for such student engagement it was necessary to take into account some particular circumstances:

- The long term nature of some of the new build projects (5 years for London College of Communication and London College of Fashion) means that any students involved now, are unlikely to still be students when the new builds are completed.

- Ascertaining learning space needs and requirements in the future

- Engagement current students in order to have an impact on both the long term and the short term? (i.e. whilst they are still students) 
UAL Library Service therefore embarked upon a substantive UX project, which was designed in order to engage students in the design and planning of the new library spaces, but also in the performance measurement of the existing library spaces. This was regarded as a key objective of the project in that students would potentially see the benefits of any developments themselves in the short term. The UX project at UAL allowed Library Services to explore current student learning behaviours in order to effectively develop library and learning spaces both presently and in the future. The UAL Library Services UX project used specific specific observational and qualitative methods for gathering intelligence within the overall methodology:

- Observation of student movements within library spaces - this is achieved through placing observers at vantage points throughout the libraries and Learning Zones, and at specific times of the day to observe and map how students move through given learning spaces. This is a popular way to see if signposting works, or whether students use particular preferred routes through the library and of there are particular physical paths of least resistance within spaces. It is also a good method to see where the popular or unpopular destinations are.

- Observation of static spaces - this technique places observers at particular vantage points (i.e. communal areas, silent zones, photocopy areas) to see how the area or space is naturally used. This achieves some of the objectives of the space observations, but also allows the observer to see which natural behaviours occur within given areas.

- Touchstone tours - Touchstone tours involve walking around the Library or Learning Zone with the user being observed in order to question and discuss the user's regular experience of the space. This allows for individuals to present their subjective views. Obtaining a critical mass of these within a given learning space can help to establish well used and underused areas of the space as well as common likes and dislikes. It is also a useful channel for getting suggestions for service improvements from users.

One of the unique elements of the UAL UX project, and why it can be used as a good example of how to engage students, is the way in which current students were deployed in order to complete the anthropological field work. As well as needing to observe students and engage them in touchstone tours, students were also engaged in facilitating the project, and a team of 12 current UAL students, representative of the university's six colleges, was recruited and deployed to spend two weeks carrying out the observations in all of the college Libraries and Learning Zones. The team was trained in the observational techniques and their time was split evenly amongst the three observational methods described above. Once 
the observation phase had been completed the student observers took part in a 'debrief' day, where their insight into what they had observed was surfaced as well as engaging in a discussion about the actual observation methods, in order to find out what worked well, and what could be refined in the methods, if the UX approach was to be used again in the future. One of the outputs from the 'debrief' day was the headline themes which had come from the observations. These were then used in a series of focus group, held at each college in order to research the students' experiences of their library spaces more deeply. More students were then engaged in participating in the focus groups and in completing reflective journals about their use of learning spaces.

Student representatives were then further engaged during the data analysis period in the summer of 2015 , as some of the original observation team were then employed to perform the data analysis on all the individual element of the UX project (i.e. observations, focus groups, reflective logs) for the final reporting and recommendations for both short and long term library space design and planning.

\section{$\underline{\text { Conclusion }}$}

The UAL UX project has provided a useful example of using a mixed qualitative method approach for engaging students in library space planning. Being able to adopt such a methodology as a formal channel of student engagement and as an instrument for consultative service improvement has proved invaluable for UAL Library Services in this instance. Throughout the paper other examples have been provided which have aimed to illustrate how a range of qualitative method can be used in order engage students in performance measurement of libraries. The examples have focused largely on focus groups, reflective journals and UX and all have been applied to student engagement in the planning and design of library space, a an easily accessible area for students to be engaged in. Through placing the user at the heart of the method. The qualitative methods discussed really harness the concept of the student as the customer and really focuses on the quality of their experience. The methods seek to identify how the library has a positive impact on the user by finding out exactly how the user interacts and uses the library's services, facilities and resources. In particular, UX is proving to be an invaluable method in providing deep insights into what the student values about their library and similarly what they don't.

\section{$\underline{\text { References }}$}

Aitkins, J., Baines, H., Donohue, N., Hannis, J. and Patel, D. (2015) "Digging deeper: developing our capability to understand our users." SCONUL Focus No. 64, pp. 18 - 
21. Available at: https://www.sconul.ac.uk/sites/default/files/documents/6 15.pdf (accessed 30 April, 2017)

Andrews, C., Wright, S. E. and Raskin, H. (2016) "Library learning spaces: investigating libraries and investing in student feedback" Journal of Library Administration, Vol. 56 no. 6, pp. 647 - 672. DOI: 10.1080/01930826.2015.1105556

Andrews, J. and Eade, E. (2013) "Listening to students: customer journey mapping at Birmingham City University Library and Learning Resources" New Review of Academic Librarianship, Vol. 19, No. 2, pp. 161 - 177

Appleton, L. (2014), 'Tell us what you think: engaging with students in library space planning' [online] \#UKAnthrolib Blog Available at: https://ukanthrolib.wordpress.com/2014/08/19/tellus-what-you-think-engaging-with-students-in-library-space-planning/ (Accessed 30 April 2017)

Appleton, L. and Abernethy, P. (2013) "We said... we did!: a partnership approach to developing library and student support services." New Review of Academic Librarianship, Vol. 19 no. 2, pp. 208 - 220

Appleton, L, Batch, J, Olsson, T. and Reed, S., (2016) Engaging students through user experience at the Univerity of the Arts, London. SCONUL Focus, Vol. 57. pp. 59 - 67. Available at: https://www.sconul.ac.uk/sites/default/files/documents/14 20.pdf (accessed 30 April, 2017)

Bennett, S. (2006) "First questions for designing higher education learning spaces" Journal of Academic Librarianship, Vol. 33, no. 1, pp. 14 - 26

Berg, B. (2009) Qualitative Research Methods for the Social Sciences, $7^{\text {th }}$ ed. Boston, MA : Allyn and Bacon

Bloor, M, Frankland, J., Thomas, M. and Robson, K., (2002), Focus Groups in Social Research, London: Sage.

Brophy, P. (2006) Measuring Library Performance: Principles and Techniques. London : Facet Publishing.

Bryant, J., Matthews, G. \& Walton, G. (2009) 'Academic libraries and social learning space: a case study of Loughborough University Library, UK' Journal of Librarianship and Information Science, Vol. 41 no. 1, pp. $7-18$.

Carey, P. (2013a) "Representation and student engagement in higher education: a reflection on the views and experiences of course representatives." Journal of Further and Higher Education, Vol. 37 no. 1, pp. 71-88.

Carey, P. (2013b) "Student as co-producer in a marketised higher education system: a case study of students' experience of participation in curriculum design." Innovations in Education and Teaching International, Vol. 50 no. 3, pp. 250-260.

Coates, H. (2005) "The value of student engagement for higher education quality assurance”, Quality Assurance in Higher Education, Vol. 11 no. 1, pp. 25-36 
Conrad, S. and Alvarez, N. (2016) "Conversations with Web site users: using focus groups to open discussion and improve user experience. Journal of web Librarianship Vol. 10 no. 2, pp. 53 - 82 DOI: 10.1080/19322909.2016.1161572

Delcore, H. D., Mullooly, J., Scroggins, M., Arnold, K., Franco, E., \& Gaspar, J. (2009). The Library Study at Fresno State. Available at: http://www.fresnostate.edu/socialsciences/anthropology/ipa/thelibrarystudy.html (accessed 30 April, 2017)

Department for Business, Innovation and Skills, (2011). Higher Education: Students at the Heart of the System. London, Dept. for Business, Innovation and Skills

Department for Business, Innovation and Skills, (2016). Success as a Knowledge Economy: Teaching Excellence, Social Mobility and Student Choice. London, Dept. for Business, Innovation and Skills

Duke, L. M.,\& Asher, A. D. (Eds.). (2012). College Libraries and Student Culture: What We Now Know. Chicago: American Library Association.

Esson, R., Stevenson, A., Gildea, M. and Roberts, S. (2012) "Library services for the future: engaging with our customers to determine wants and needs" Library Management, Vol. 33 no. $8 / 9$, pp. $469-478$

Everitt, R. (2015) "Stop over-thinking: basic tools for understanding stakeholder needs", SCONUL Focus, Vol. 64, pp. 27 - 30. Available at:

https://www.sconul.ac.uk/sites/default/files/documents/8 17.pdf (accessed 30 April, 2017)

Foster, N. F. and Gibbons, S. (2007). Studying Students: The Undergraduate Research Project at the University of Rochester. Chicago: Association of College and Research Libraries. Available at: http://www.ala.org/acrl/sites/ala.org.acr/files/content/publications/booksanddigitalresources/ digital/Foster-Gibbons cmpd.pdf (accessed 30 April, 2017)

Gorman, G. E. and Clayton, P. (2005) Qualitative Research for the Information Professional: a Practical Handbook, $2^{\text {nd }}$ ed. London ; Facet Publishing

Krueger, R. and Casey, M.-A. (2009), Focus Groups: a practical guide for applied research, $4^{\text {th }}$ ed. Los Angeles, Sage.

Little, B., Locke, W., Scesa, A. and Williams, R. (2009), Report to HEFCE on Student Engagement, Bristol: HEFCE

Maringe, F. (2010), "The student as consumer: affordances and constraints in a transforming higher education environment", in Molesworth, M., Scullion, R. and Nixon, E. (Eds) The Marketisation of Higher Education and The Student as Consumer, London: Routledge, pp. 142-154.

McKnight, S. and Berrington, M. (2008) "Improving customer satisfaction: changes as a result of customer value discovery". Evidence Based Library and Information Practice, Vol. 3 no. 1 , pp. $33-52$ 
Molesworth, M., Nixon, E. and Scullion, R. (2009) "Having, being and higher education: the marketisation of the university and the transformation of the student into consumer.

Teaching in Higher Education, Vol. 14 no. 3, pp. 277-87.

Morgan, D. (1997) Focus Groups as Qualitative Research, $2^{\text {nd }}$ ed. Thousand Oaks, Sage.

Nachmias, D. and Worth-Nachmias, C. (2008) Research Methods in the Social Sciences, $7^{\text {th }}$ ed. New York : Worth Publishers

Oddy, E. (2015) "Embracing the student voice", SCONUL Focus Vol. 64. pp. 31 - 33 Available at: http://www.sconul.ac.uk/sites/default/files/documents/10_14.pdf (Accessed 30 April 2016)

Owen, D. (2013) “Haven't we seen it all before?: historical themes in student engagement", in Dunne, E. \& Derfel, O. (Eds), The Student Engagement handbook: Practice in Higher Education, Bingley: Emerald, pp. 5 - 21.

Pickard, A. (2006), Research Methods in Information, London : Facet

Priestner, A. (2015) 'UXLibs: a new breed of conference’ Cilip Update (May 2015), pp. 31 33

Priestner, A. and Borg, M. (2016) "Uncovering Complexity and Detail : the UX Proposition" in A. Priestner \& M. Borg (eds) User Experience in Libraries: Applying Ethnography and Human-Centred Design. London : Routledge, pp. 1 - 8

Ramsden, B. (2016) "Using Ethnographic Methods to Study Library Use" in A. Priestner \& M. Borg (eds) User Experience in Libraries: Applying Ethnography and Human-Centred Design. London : Routledge, pp. 9 - 20

Ramsden, M. and Carey, C. (2014) "Spaces for learning?: student diary mapping at Edge Hill University" SCONUL Focus Vol. 62, pp. 7 - 10 Available at:

http://www.sconul.ac.uk/sites/default/files/documents/3_13.pdf (Accessed 30 April 2017)

Saunders, D. B. (2015) "They do not buy it: exploring the extent to which entering first-year students view themselves as customers" Journal of Marketing for Higher Education Vol. 25 no. 1 , pp. 5 - 28

Schmidt, A. (2010) "New column launch: the user experience. Library Journal, January 2015. Available at: http://lj.libraryjournal.com/2010/01/opinion/aaron-schmidt/new-column-launchthe-user-experience/ (accessed 30 April, 2017)

Slater, M. (1990), Research Methods in Library and Information Studies. London : Library Association

Stone, G, Pattern, D. and Ramsden, B. (2012), "The Library Impact Data Project: hit, miss or maybe." in Hall, I., Thornton, S. and Town, S. (eds) Proving value in challenging times: proceedings of the 9th Northumbria International Conference on Performance Measurement in Libraries and Information Services. University of York Press, York, pp. $385-390$. 
Streeting, W. and Wise, G. (2009) Rethinking the Values of Higher Education: Consumption, Partnership, Community?, Gloucester: Quality Assurance Agency for Higher Education.

Sykes, E. (2015) "Gathering user insight on a shoestring" SCONUL Focus Vol. 64, pp. 68 - 71 Available at:

https://www.sconul.ac.uk/sites/default/files/documents/18_12.pdf (accessed 30 April, 2017)

Suarez, D. (2007). "What students do when they study in the library: using ethnographic methods to observe student behavior." Electronic Journal of Academic and Special Librarianship, Vol. 8 no. 3, pp. 1-19. Available at:

http://southernlibrarianship.icaap.org/content/v08n03/suarez d01.html (accessed 30 April, 2017)

Trischler, J. and Kelly, K. (2016) "User involvement in the design of new library services; learning from the application of Codesign on library service design projects. In Atkinson, J. (ed.) Quality and the Academic Library: Reviewing, Asessing and Enhancing Service Provision. Cambridge (MA): Chandos. pp. $111-120$.

Tilley, E. (2013) "Personalised boutique services: critical to academic library success?" New Review of Academic Librarianship, Vol. 19 no. 1, pp. 78 - 97

Tomlinson, M. (2017) "Student perceptions of themselves and 'consumers' of higher education" British Journal of Sociology of Education Vol. 34 no. 4, pp. 450 - 467

Trowler, V. (2010) Student Engagement Literature Review, York: Higher Education Academy.

White, C. T. (2009). Studying Students: The Ethnographic Research Project at Rutgers (part 2). Available at:

http://www.libraries.rutgers.edu/rul/staff/groups/ethnography/reports/ERP FinalReport Phas e 2.pdf (accessed 30 April, 2017)

\section{$\underline{\text { Notes }}$}

1. http://www.erialproject.org/

2. http://www.fresnostate.edu/socialsciences/anthropology/ipa/thelibrarystudy.html 